\title{
Changes in Osmotic Adjustment and Antioxidant Enzyme in Maize (Zea mays L.) Root Exposed to K Deficiency
}

\author{
Qi Du1,2, Tuo Zou1, Leiyue Geng1, Wei Zhang1, Xiaoguang Wang2, \\ Haiqiu Yu' ${ }^{2}$ Xinhua Zhao ${ }^{2 *}$ \\ ${ }^{1}$ Coastal Agriculture Institute, Hebei Academy of Agricultural and Forestry Sciences, Tangshan, China \\ ${ }^{2}$ College of Agronomy, Shenyang Agricultural University, Shenyang, China \\ Email: *xinhua-zhao@syau.edu.cn
}

How to cite this paper: Du, Q., Zou, T., Geng, L.Y., Zhang, W., Wang, X.G., Yu, H.Q. and Zhao, X.H. (2021) Changes in Osmotic Adjustment and Antioxidant Enzyme in Maize (Zea mays L.) Root Exposed to $\mathrm{K}$ Deficiency. Journal of Agricultural Chemistry and Environment, 10, 359-371.

https://doi.org/10.4236/jacen.2021.103023

Received: July 7, 2021

Accepted: August 6, 2021

Published: August 9, 2021

Copyright $\odot 2021$ by author(s) and Scientific Research Publishing Inc. This work is licensed under the Creative Commons Attribution International License (CC BY 4.0).

http://creativecommons.org/licenses/by/4.0/

(c) (i) Open Access

\begin{abstract}
Potassium (K) deficiency damaged membrane stability through irregular reactive oxygen species (ROS) caused by $\mathrm{K}$ deficiency stress while osmotic adjustment and antioxidant capacities play an essential role in preventing plants from osmotic stress and oxidative damages. To investigate the difference of osmoprotectants and antioxidant enzyme activities in the root, two representative maize varieties, 90-21-3 (K-tolerant) and D937 (K-sensitive), were hydroponically cultivated under normal $\mathrm{K}(+\mathrm{K})$ and $\mathrm{K}$ deficiency $(-\mathrm{K})$ treatments in Shenyang Agriculture University, China. The results showed that root accumulation, soluble protein in root of 90-21-3 and D937 were decreased under $\mathrm{K}$ deficiency stress, but the root to shoot ratio, proline, free amino acid, soluble sugar, reactive oxygen species (ROS) in root for both genotypes were increased. Compared with the root of D937, the root of 90-21-3 was able to swiftly accumulate more proline, free amino acid and soluble sugar in the root when encountering $\mathrm{K}$ deficiency. The antioxidant enzyme activity in the root of 90-21-3, including superoxide dismutase (SOD), and catalase (CAT), peroxidase (POD), were significantly increased to counter increased levels of $\mathrm{O}_{2} \cdot{ }^{-}$and $\mathrm{H}_{2} \mathrm{O}_{2}$ under $\mathrm{K}$ deficiency stress. The presented results indicated that osmotic regulator and antioxidant enzyme were actively responded to $\mathrm{K}$ deficiency stress, 90-21-3 (K-tolerant maize) accumulated more osmoprotectants and enhanced the activity of antioxidant enzymes to degrade ROS, alleviating oxidative stress.
\end{abstract}

\section{Keywords}

Maize, K Deficiency, Root, ROS, Osmoprotectant and Antioxidase 


\section{Introduction}

$\mathrm{K}$, as a major mineral element, plays an essential role in process of crop growth and development, involved in function of osmoregulation, enzyme activation, ion homeostasis, and transport of metabolites in plants [1]. However, compared with application of nitrogen $(\mathrm{N})$ and phosphorus $(\mathrm{P}), \mathrm{K}$ fertilizer is typically applied at a lower level in intensive agricultural production. An ongoing downward trend of negative $\mathrm{K}$ balance of about $60 \mathrm{~kg} \mathrm{ha}^{-1} \cdot \mathrm{yr}^{-1}$ appeared in intensive agricultural production areas starting in the late 1990s due to improper fertilization [2]. Consistent with the trend, more than $3 / 4$ of soil of China has been reported deficient in available $\mathrm{K}$ [3]. Distinctly, the $\mathrm{K}$ deficiency has given rise to seriously inhibiting root growth and development caused by osmotic stress and oxidative stress.

Plants have developed various defense mechanisms in process of long-term evolution to survive the deleterious effects of environment stress. Osmoregulators can improve stress tolerance in plants by actively increasing levels of materials that can adjust the osmotic cellular conditions, including inorganic ions and organic solutes [4]. Inorganic ions and organic solutes are primary components that participate in osmotic adjustment in response to stress and contribute to stress tolerance in plants [5] [6]. $\mathrm{Na}^{+}$and $\mathrm{Ca}^{2+}$ in vacuoles were verified that could substitute for $\mathrm{K}^{+}$in osmotic adjustment function which could effectively reduce the negative effects caused by the lack of $\mathrm{K}^{+}$[3] [7]. And, the accumulated proline, soluble sugar, and phenol could reduce the osmotic stress caused by $\mathrm{Fe}^{2+}, \mathrm{Zn}^{2+}$, and $\mathrm{Mn}^{2+}$ deficiency, and improve plant tolerance [8].

$\mathrm{K}$ deficiency disrupted equilibrium of ROS that impeded crop growth due to accumulation of $\mathrm{O}_{2} \cdot{ }^{-}$and $\mathrm{H}_{2} \mathrm{O}_{2}$ in roots [9]. ROS disorganized cell physiological function by oxidizing proteins, damaging nucleic acids and causing lipid peroxidation. However, antioxidant systems played decisive roles in scavenging ROS and protecting against destructive oxidative reactions [10]. Antioxidant enzymes in cell can effectively resist oxidative stress damage and reduce the ability of ROS [11]. Besides being a potentially harmful destructor, ROS is a key player in the process of stress responses in complex signaling network. The expression of a high-affinity potassium transporter, $\mathrm{HAK} 5$, was triggered by the $\mathrm{H}_{2} \mathrm{O}_{2}$ produced under $\mathrm{K}$ deficiency [12]. Min et al. [13] also found that POD could affect the expression of AtHAK5 by regulation of ROS. Meanwhile, POD also acted as important antioxidant enzyme to scavenge peroxides and was essential in the balance of ROS [14].

Maize (Zea mays L.) is an important cereal crop with higher demand for potash fertilizer than other crops. More efficient osmoprotection and antioxidation mechanisms could enhance the ability resistance to abiotic stress [15]. However, significant differences have been well documented for osmotic adjustment and antioxidant enzyme activity in different genotypes. "Arper" accumulated more organic solutes than "Aristo" to mitigate osmotic stress in root of maize under salt stress [6]. "Eyou Changiia" (P use-efficient genotype) of Brassica napus en- 
hanced more antioxidant enzyme activities than "B104-2" (P use-inefficient genotype) under $\mathrm{P}$ deficiency stress [16]. However, the activity of osmoregulation and antioxidant enzymes in maize root under $\mathrm{K}$ deficiency stress was little attention to reporting. The present study was aimed to assess the effect of osmoregulatory and antioxidant enzymes activity changed on oxidative stress in 90-21-3 (K-tolerant) and D937 (K-sensitive) under K deficiency stress.

\section{Materials and Methods}

\subsection{Plant Material and Growth Conditions}

Two genotypic difference maize, 90-21-3 (K-tolerant) and D937 (K-sensitive), were screened from more than total 2000 lines cultivated based on growth and yield for over ten years in Liaozhong County of China that $\mathrm{K}$ fertilizer has not been supplied since 2000, a naturally K deficient field (available K less than 50.4 $\left.\mathrm{mg} \cdot \mathrm{kg}^{-1}\right)$. Then the materials were verified through the performance in field trial, pool trial and hydroponically trial in 2016. Differed from 90-21-3 that no visible symptoms, the D937 showed leaf blades turned yellow at the seedling stage under K deficiency soil. The mature 90-21-3 plants exhibited significantly higher biomass and grain yield than D937 grown in the K-deficient soil. Both 90-21-3 and D937 were from "Ludahonggu" cultivars and "Reid" cultivars in China, respectively.

The experiment was conducted by the way of hydroponic method in Shenyang Agricultural University, China. Uniform seeds were chosen and sterilized in $7 \% \mathrm{NaClO}_{3}$ solution, then germinated in sterile silica sand on July 1, 2016. The seedlings with two visible leaves (about 1 week) were wiped off endosperm carefully and then transplanted into black plastic buckets containing nutrient solution. Random block arrangement was repeated four times. The component was 1/2 Hoagland's nutrient solution modified from Cao et al. [17], and containing $(\mu \mathrm{mol} / \mathrm{L}) 2000 \mathrm{Ca}\left(\mathrm{NO}_{3}\right)_{2}, 2000 \mathrm{NaNO}_{3}, 2500 \mathrm{KCl}, 1000 \mathrm{MgSO}_{4}, 500$ $\mathrm{NH}_{4} \mathrm{H}_{2} \mathrm{PO}_{4}, 100$ EDTA-Fe(II), $22.5 \mathrm{MnCl}_{2}, 115 \mathrm{H}_{3} \mathrm{BO}_{3}, 0.75 \mathrm{ZnSO}_{4}, 0.16 \mathrm{CuSO}_{4}$, and $0.182\left(\mathrm{NH}_{4}\right)_{6} \mathrm{Mo}_{7} \mathrm{O}_{24}$. The solution was regulated by $0.1 \mathrm{~mol} \mathrm{NaOH}$ and $\mathrm{HCl}$ to $\mathrm{pH}$ 6.0. Air added into the buckets through air stone that provided oxygen for roots at a rate of $40 \mathrm{~min} \mathrm{~h}^{-1}$.

After seven days of cultivation, one half seedlings were transferred into new nutrient solution (controls), while the rest were carefully washed by deionized water more than 3 times, and then transferred into boxes with K-deficient nutrient solution. The roots were sampled after detached and washed with deionized water after $1 \mathrm{~d}, 3 \mathrm{~d}, 5 \mathrm{~d}$, or $7 \mathrm{~d}$ of $\mathrm{K}$ deficiency treatment, and frozen rapidly in liquid nitrogen prior to measurement of osmoprotectants, ROS, and antioxidase activity.

\subsection{Biochemical Analysis}

\subsubsection{Osmoprotectants}

The proline concentration was estimated by monitoring the absorbance of reac- 
tant between acid indene and proline at $528 \mathrm{~nm}$ with an UV-VIS spectrophotometer (PerkinElmer Lambda 365, USA) as described by Ashraf and Zafar [18]. Free amino acid concentration was analyzed by color-developing reagent (triketohydrindene hydrate) at $530 \mathrm{~nm}$ according to Hajlaoui et al. [6]. Soluble sugar content was measured by monitoring the absorbance of anthrone reagent at 630 $\mathrm{nm}$ according to Wan et al. [19]. Soluble protein contents were analyzed by Coomassie Brilliant Blue (G-250) solution at $595 \mathrm{~nm}$ according to Bradford [20].

\subsection{2. $\mathrm{O}_{2}{ }^{-}, \mathrm{H}_{2} \mathrm{O}_{2}$, and MDA}

Superoxide anion $\left(\mathrm{O}_{2}{ }^{-}\right)$production was estimated by monitoring the absorbance of reactant among hydroxylamine hydrochloride, a-naphthylamine and enzyme solution at $530 \mathrm{~nm}$ with an UV-VIS spectrophotometer (PerkinElmer Lambda 365 , USA) according to Tian et al. [21]. The hydrogen peroxide $\left(\mathrm{H}_{2} \mathrm{O}_{2}\right)$ level was estimated by the increased absorbance of reactant between extracting solution and $0.1 \%$ titanium chloride in $20 \%(\mathrm{v} / \mathrm{v}) \mathrm{H}_{2} \mathrm{SO}_{4}$ at $410 \mathrm{~nm}$ as described by Tsai et al. [22]. The malondialdehyde (MDA) content was measured with thiobarbituric acid at $532 \mathrm{~nm}$ and $600 \mathrm{~nm}$ as described in Mir et al. [23].

\subsubsection{SOD, POD, and CAT}

The enzyme extraction was performed according to Grace and Logan [24]. Enzymatic protein was extracted with $50 \mathrm{mM} / \mathrm{L}$ cold phosphate buffer ( $\mathrm{pH} 7.8$ ) containing $0.1 \mathrm{mM}$ EDTA and 2\% PVP. The supernatant solution was centrifuged at $15,000 \mathrm{~g}$ at $4^{\circ} \mathrm{C}$ to determine enzymatic assays.

Superoxide dismutase (SOD) activity was determined by the absorbance at $560 \mathrm{~nm}$ as described by Neto et al. [25]. One unit of enzyme activity was regarded as the value of SOD required to produce a $50 \%$ inhibition of reduction of nitroblue tetrazolium. POD and CAT activities were tested according to Tian et al. [21]. One unit of POD activity was defined as the increase in the absorbance of $0.01 \mathrm{~min}^{-1}$ per gram fresh weight at $470 \mathrm{~nm}$. One unit of CAT was defined as the decrease in absorbance of $0.01 \mathrm{~min}^{-1}$ per gram fresh weight at $240 \mathrm{~nm}$.

\subsection{Statistical Analysis}

Four replicates of each treatment were performed to an analysis of variance with the SPSS19.0 software (SPSS Inc., Chicago, IL, USA). Differences between mean values were tested using the least significant difference ( $L S D)$ at a probability level of 0.05 , which were indicated by different letters. All tables and figures were made using the Excel 2013.

\section{Results}

\subsection{Growth}

Compared with controls, total dry weight of 90-21-3 and D937 were decreased by $13.62 \%$ and $27.83 \%$ under $\mathrm{K}$ deficiency stress at $7 \mathrm{~d}$, respectively (Figure 1 (a)). The root and shoot weight of $90-21-3$ were decreased by $7.90 \%$ and $13.15 \%$ in comparison with the controls after $7 \mathrm{~d}$ of $\mathrm{K}$-starvation, and significantly decreased 

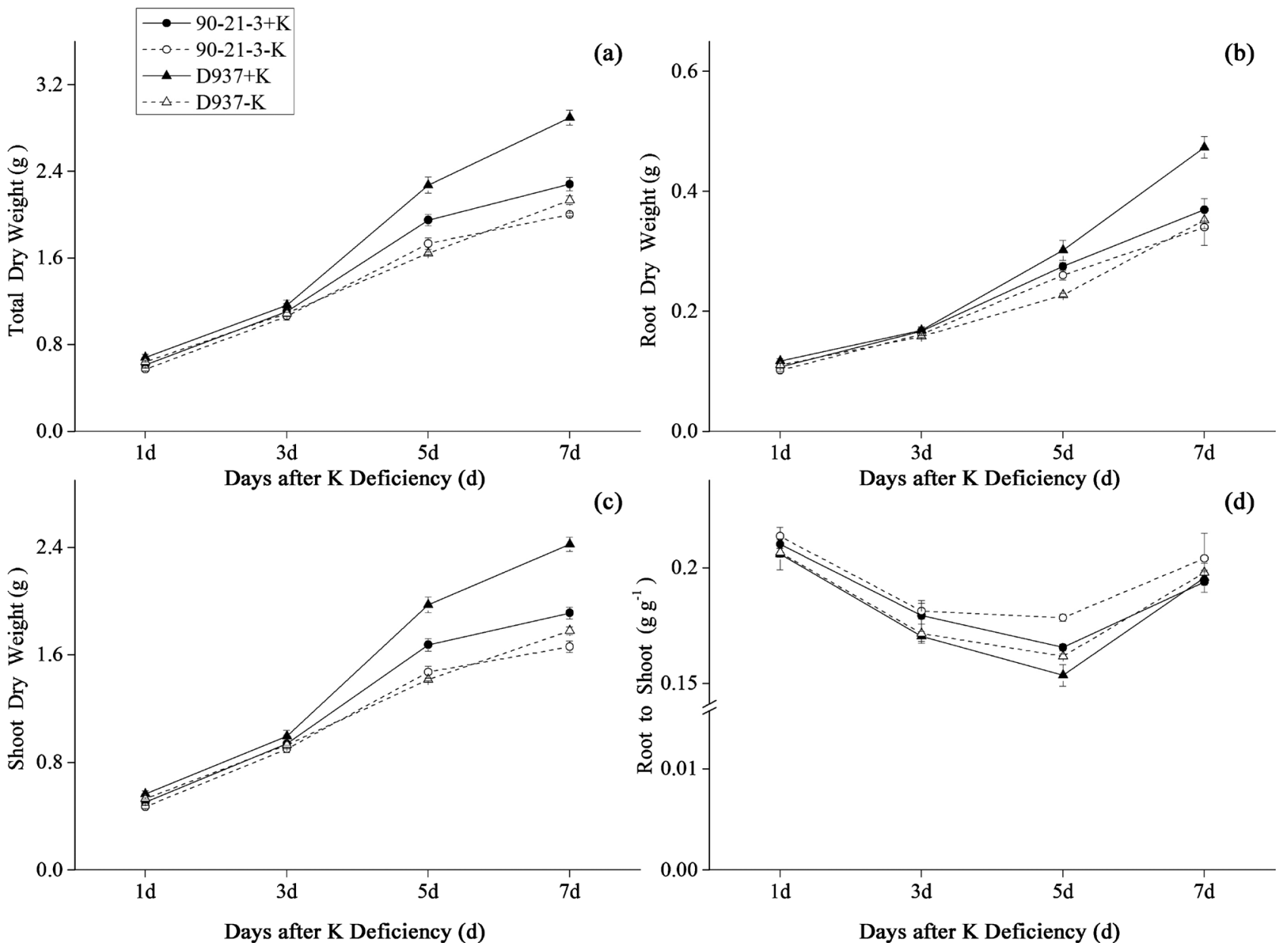

Figure 1. Time course of dry accumulation in two maize genotypes, 90-21-3 and D937, grown under control conditions and $\mathrm{K}$ starvation. (a) Total dry weight, (b) root dry weight, (c) shoot dry weight, and (d) R/S. Dates are expressed as means of 4 replicates and the bars indicate the standard errors.

by $25.59 \%$ and $26.54 \%$ in D937 (Figure 1 (b) and Figure $1(\mathrm{c})$ ), respectively. Obviously, more reduction in shoots than in roots of 90-21-3 and D937 was showed under $\mathrm{K}$ deficiency treatment. The root to shoot ratio $(\mathrm{R} / \mathrm{S})$ was significantly increased by $23.23 \%$ for $90-21-3$ at $7 \mathrm{~d}$ of K-deficiency, but less dramatically increased in D937 (Figure 1(d)).

\subsection{ROS and MDA Content}

$\mathrm{O}_{2} \cdot{ }^{-}$accumulated in two genotypes under $\mathrm{K}$-free treatment (Figure 2(a)). In 90-21-3, the $\mathrm{O}_{2} \cdot{ }^{-}$concentration in the root increased rapidly by $18.06 \%$ and $13.55 \%$ at $1 \mathrm{~d}$ and $3 \mathrm{~d}$ relative to controls after $\mathrm{K}$ withdrawal, but just $3.45 \%$ and $1.02 \%$ at $5 \mathrm{~d}$ and $7 \mathrm{~d}$, respectively. In D937, however, the $\mathrm{O}_{2} \cdot{ }^{-}$concentration in D937 was increased by $10.38 \%$ and $6.03 \%$ than the control at $1 \mathrm{~d}$ and $3 \mathrm{~d}$, and significantly increased by $26.65 \%$ and $13.04 \%$ at $5 \mathrm{~d}$ and $7 \mathrm{~d}$ of $\mathrm{K}$ deficiency, respectively. The $\mathrm{H}_{2} \mathrm{O}_{2}$ in 90-21-3 was little changed, but significantly increased by $27.65 \%$ in root of D937 after $7 \mathrm{~d}$ of K-deficiency treatment (Figure 2(b)). MDA in root of D937 was significantly increased by $41.04 \%$ and $40.26 \%$ in comparison 


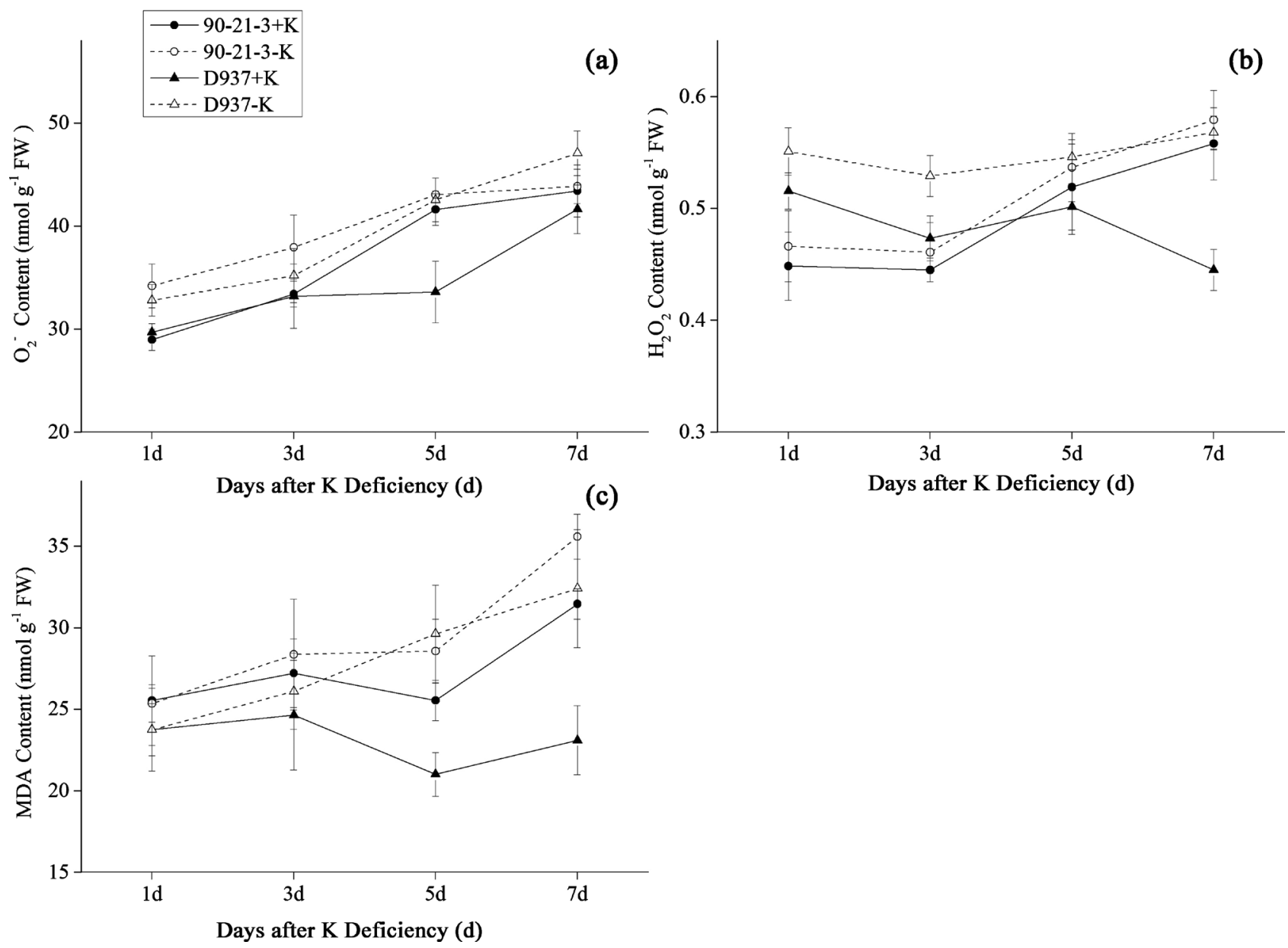

Figure 2. Time course of ROS in 90-21-3 and D937 maize genotypes grown under control treatment conditions and potassium starvation. (a) Superoxide anion $\left(\mathrm{O}_{2} \cdot{ }^{-}\right)$content, (b) hydrogen peroxide $\left(\mathrm{H}_{2} \mathrm{O}_{2}\right)$ content, (c) lipid peroxidation (MDA) content.

with the controls after $5 \mathrm{~d}$ and $7 \mathrm{~d}$ of K-starvation, and higher than the observed increases of $11.86 \%$ and $13.13 \%$ in $90-21-3$ (Figure $2(\mathrm{c})$ ).

\subsection{Osmoprotectants Content}

As shown in Figure 3(a), proline in D937 was significantly increased by $25.86 \%$ after $1 \mathrm{~d}$ of $\mathrm{K}$-free starvation, and significantly increased by $9.62 \%, 12.03 \%$, $21.15 \%$, and $26.22 \%$ in $90-21-3$ at $1 \mathrm{~d}, 3 \mathrm{~d}, 5 \mathrm{~d}$, and $7 \mathrm{~d}$, respectively. An increase of free amino acids in roots of both lines responded to K-deficient treatment conditions (Figure 3(b)). The amount in 90-21-3 was significantly increased by $26.19 \%, 20.35 \%, 14.33 \%$, and $24.63 \%$ relative to controls after $1 \mathrm{~d}, 3 \mathrm{~d}, 5 \mathrm{~d}$, and 7 d, respectively, of $\mathrm{K}$ withdrawal, and $10.20 \%, 9.54 \%, 11.70 \%$, and $19.66 \%$, respectively, in D937.

As shown in Figure 3(c), $\mathrm{K}$ deficiency treatment positively stimulated soluble sugar in 90-21-3 and D937. Compared with controls, 90-21-3 was increased by $20.79 \%$ after $5 \mathrm{~d}$ of $\mathrm{K}$ deficiency, respectively, and increased of $9.99 \%$ in D937. Contrary to the variation of soluble sugar, the soluble protein in both roots was decreased under K-deficiency treatment (Figure 3(d)). The soluble protein in 

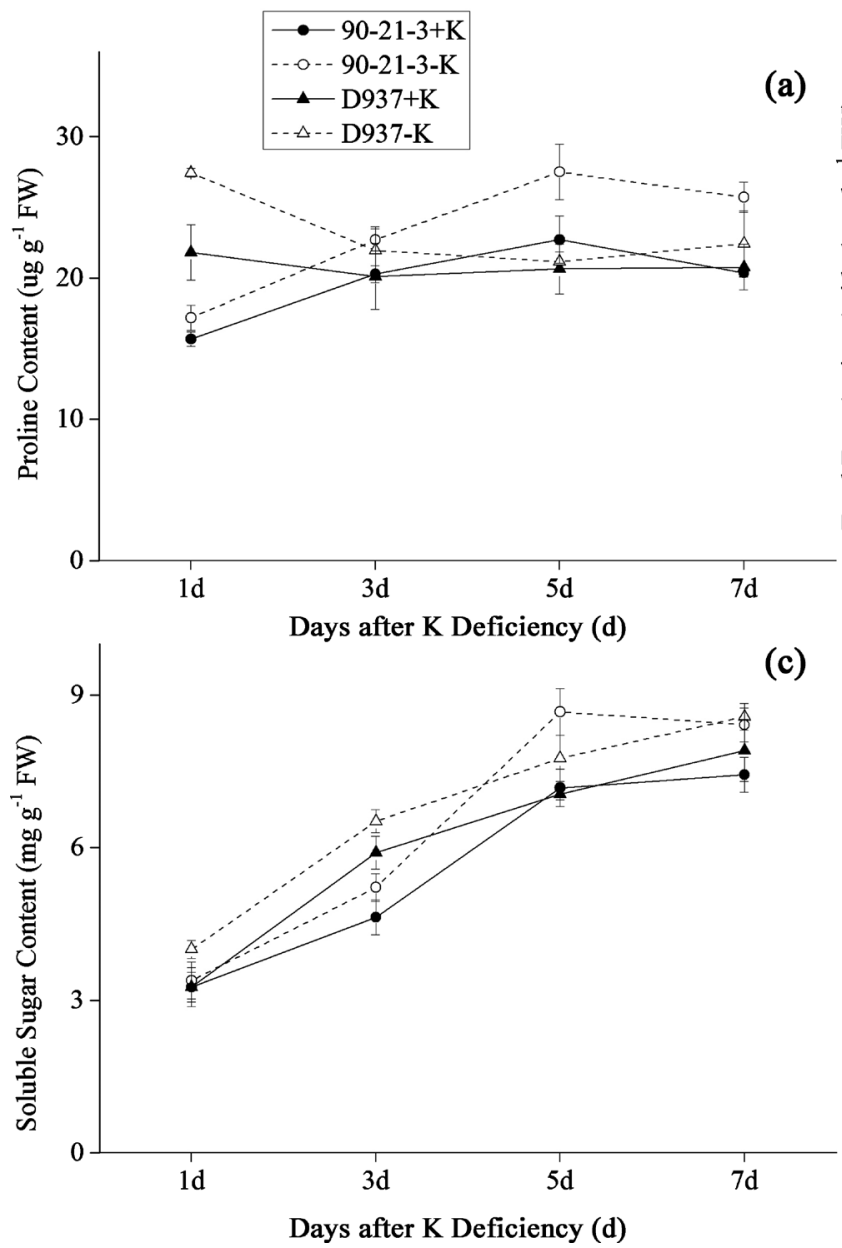
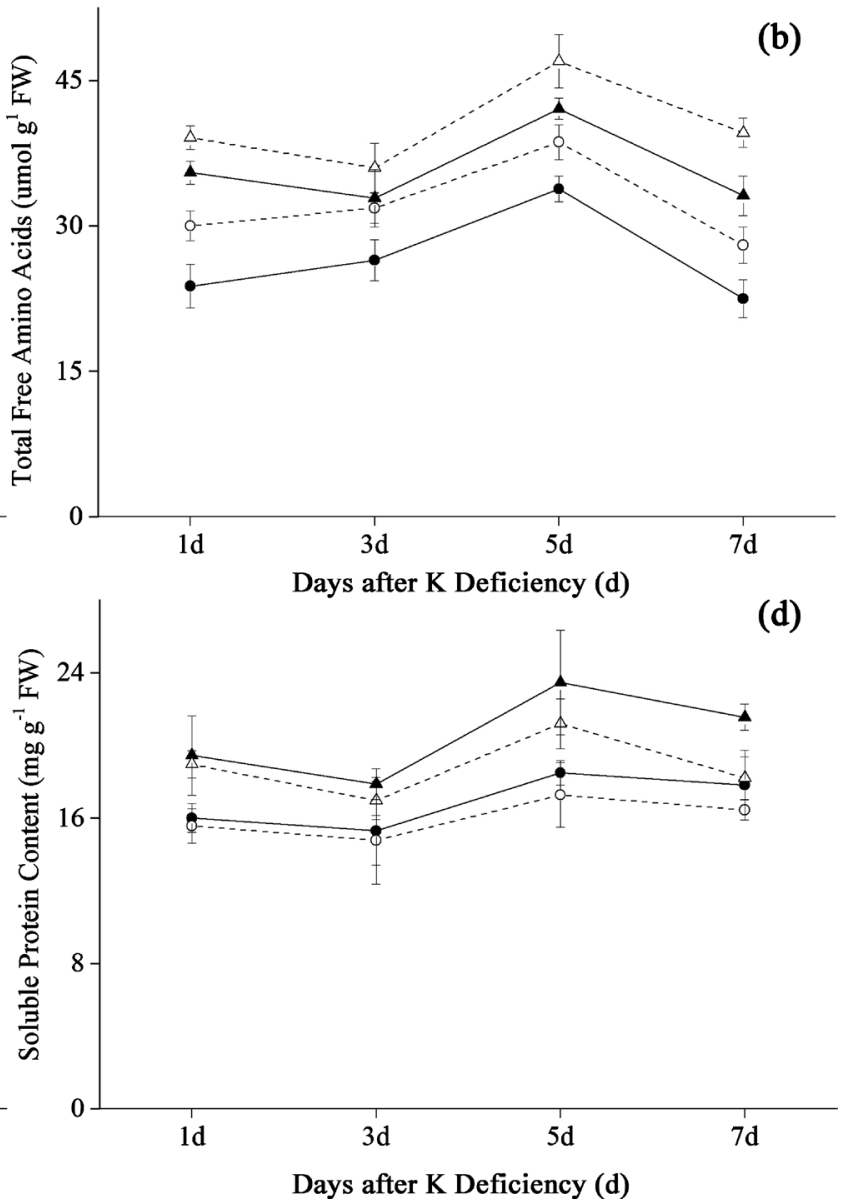

Figure 3. Time course of organic solutes in 90-21-3 and D937 maize genotypes grown under control treatment and potassium starvation. (a) Proline, (b) free amino acids, (c) soluble sugar and (d) soluble protein in roots of 90-21-3 and D937.

90-21-3 was decreased by $7.69 \%$ at $7 \mathrm{~d}$ under K-deficiency treatment, and decreased by $15.57 \%$ in D937, respectively.

\subsection{Antioxidase Activity}

SOD activity in $90-21-3$ and D937 was dramatically increased by $24.51 \%$ and $10.55 \%$ in comparison to controls after 1d of K-starvation, respectively (Figure 4(a)). However, the D937 was significantly decreased by $15.04 \%, 17.42 \%$, and $6.90 \%$ at $3 \mathrm{~d}, 5 \mathrm{~d}$ and $7 \mathrm{~d}$ treatment after $\mathrm{K}$ withdrawal, but increase of $14.47 \%, 13.20 \%$, and $3.24 \%$ in 90-21-3. Compared with controls, the POD activity in root of 90-21-3 was differently increased by $20.86 \%$ at $7 \mathrm{~d}$, but significantly decreased by $11.86 \%$ in D937 (Figure 4(b)). CAT enzyme activity in 90-21-3 and D937 were dramatically increased after $1 \mathrm{~d}$ of $\mathrm{K}$ starvation stress (Figure 4(c)). After $5 \mathrm{~d}$ of K-deficiency stress, the CAT kept higher activity in 90-21-3 than in the control, but there was a significant decrease of $11.79 \%$ in D937, compared to without treatment.

\section{Discussion}

Root system played an essential role in process of nutrient absorption, hormone 


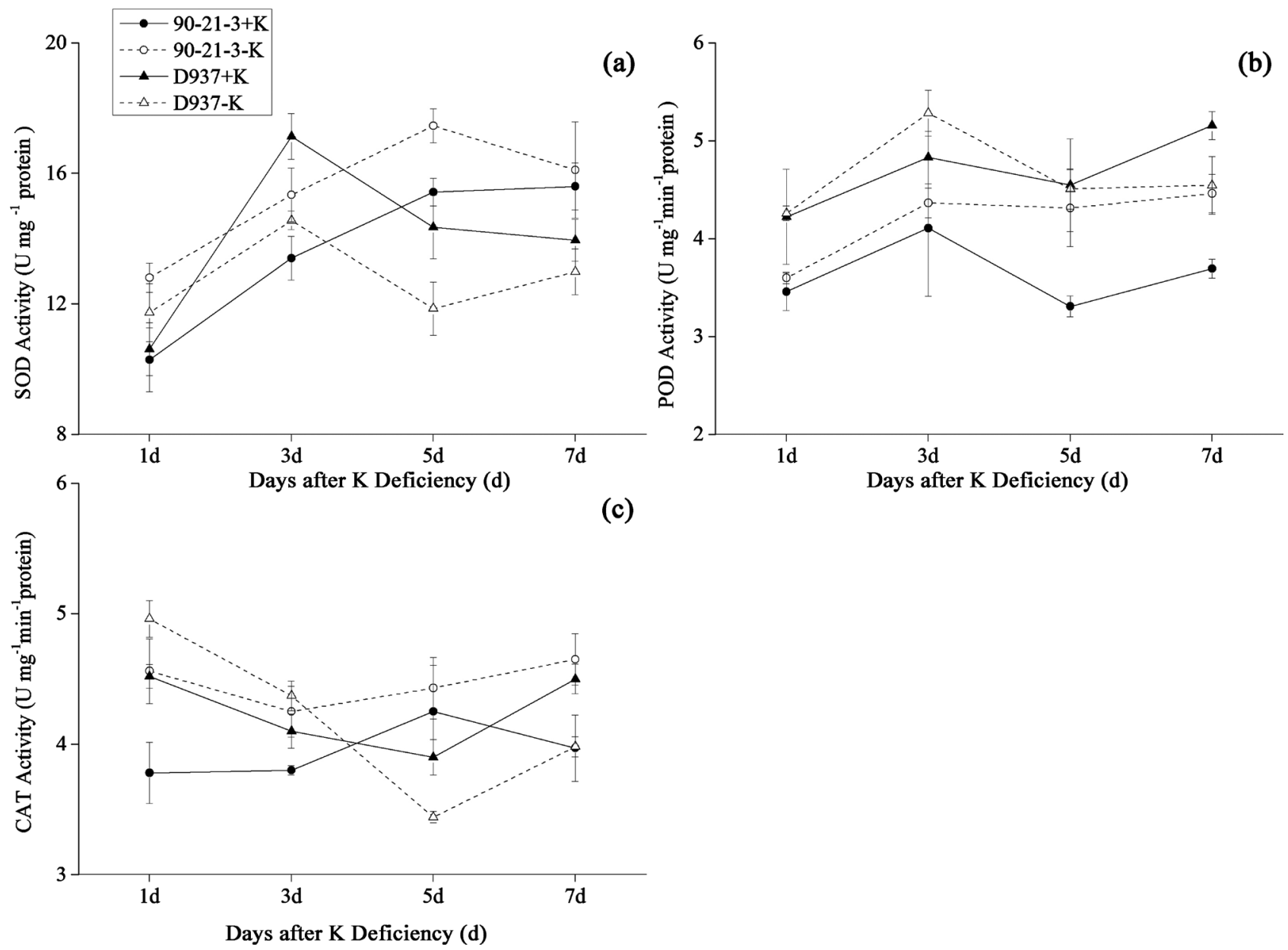

Figure 4. Time course of antioxidase in 90-21-3 and D937 maize genotypes grown under control treatment conditions and potassium starvation. (a) Superoxide dismutase (SOD), (b) peroxidase (POD) and (c) catalase (CAT).

synthesis, organic acids and amino acids exudation, etc. $\mathrm{K}^{+}$, as a monovalent cation, is involved in physiological processes such as determining the osmotic potential and enzyme activation. However, the rhizosphere is often in a state of $\mathrm{K}$ deficiency due to low absorption of roots grown in soil with low available $\mathrm{K}$ content. $\mathrm{K}$ deficiency could inhibit plant growth by damage of the membrane structure and hindering photosynthesis [26]. Here, the growth of 90-21-3 and D937 was obviously dropped, but 90-21-3 maintained more root weight than D937 under K-deficiency stress. Distinctly, the shoot showed more serious inhibition than the roots under K deficiency. Similar results were reported by Jordan-Meille and Pellerin [27]. Differently from Tewari et al. [28] that the reduction in R/S, in present study, R/S in 90-21-3 was more increased than D937 under K-deficiency stress. This indicated that more carbohydrate was redistributed in 90-21-3 from shoots to roots to promote root growth, allowing root exploring of larger soil to loot more $\mathrm{K}^{+}$.

Osmoregulation is an important mechanism involved in the defense against stress by regulating osmotic potential. Under $\mathrm{K}$ deficiency stress, the decreased $\mathrm{K}^{+}$ in root affected osmotic pressure in the xylem, which could inhibit long-distance 
sap flow from roots to shoots [29]. Biosynthesis and accumulation of organic solutes in vacuoles and the cytosol may be involved in membrane stability [30]. Proline is regarded as an osmoprotectant, ROS scavenger and inhibitor of lipid peroxidation, etc. [31]. In our study, the proline level, one sensitive of free amino acids, was greater increased with longer treatment time in 90-21-3 than in D937. The increased proline could help to balance the vacuole osmotic potential in roots and maintain the ratio of $\mathrm{NADH} / \mathrm{NAD}^{+}$under $\mathrm{K}$ deficiency to reduce the disorganization of the electron transport chain. Under a shortage of micronutrients $\left(\mathrm{Zn}^{2+}, \mathrm{Fe}^{2+}\right.$, and $\left.\mathrm{Mn}^{2+}\right)$, soluble sugar was significantly increased to boost osmotic stress tolerance in two lettuce cultivars [8]. Similar results were reported in roots of alfalfa [32] and Arabidopsis [33]. $\mathrm{K}^{+}$was involved in transportation of carbohydrate synthesized by leaf photosynthesis by way of phloem [34]. The soluble sugar in root of 90-21-3 indicated that more carbohydrates were transported into roots than to shoots, stimulating axile root elongation after $\mathrm{K}$ deprivation, and also was indicated by an increased root to shoot ratio [27] [35]. But, nitrate assimilation and protein synthesis were strongly impeded by $\mathrm{K}$ deficiency due to the altered nitrogen metabolism enzymes activities, although amino acids increased [33] [36].

Membrane lipid peroxidation was induced by an increase in ROS due to blocking electron transport under $\mathrm{K}$ deficiency stress. The cell structure and function could become disordered by abnormal ROS that damage nucleic acids, oxidize proteins, and cause lipid peroxidation [9]. The increased MDA value indicated the root cell was suffered from oxidative stress and more serious oxidative damage of lipids occurred in the roots of D937 than in 90-21-3, which suggested stronger scavenging ability of ROS in 90-21-3 than D937 under K deficiency conditions.

Antioxidant enzyme systems were regarded as crucial participator in scavenging and eliminating ROS in plants. Evidences indicated that stress-tolerant genotypes may promote defense system depending on enhancement of antioxidant enzymes [16]. The accumulation of oxidative damage in potassium-starved maize seedlings indicated disruption of the balanced state between ROS production and antioxidant defense system. The SOD activity decreased in D937 and $\mathrm{O}_{2}{ }^{-}$ accumulated with time of $\mathrm{K}$ deficiency, but 90-21-3 remained high activity in 90-21-3. Although $\mathrm{O}_{2} \cdot{ }^{-}$could be translated into $\mathrm{H}_{2} \mathrm{O}_{2}$ by disproportionate of SOD to mitigate the damage of $\mathrm{O}_{2}{ }^{-}, \mathrm{H}_{2} \mathrm{O}_{2}$ continued to act as a destructor and could be eliminated by conversion to $\mathrm{H}_{2} \mathrm{O}$ through the action of POD and CAT enzymes [37]. Here, the dates showed $\mathrm{H}_{2} \mathrm{O}_{2}$ was induced to explode in response to potassium deficiency treatments, with increased POD and CAT activity. However, the POD and CAT activities of D937 were depressed, but higher enzymatic activity was observed in 90-21-3, especially POD activity. Maintaining higher activity of SOD enzymes and coordinated expression of antioxidant enzymes could improve the ability of plants to resist ROS [38]. These results suggested 90-21-3 could promote high SOD, POD and CAT enzyme activity to scavenge ROS and 
decreased membrane lipid peroxidation under K deficiency.

In conclusion, the root growth of 90-21-3 and D937 was inhibited due to osmotic stress and oxidative stress under $\mathrm{K}$ deficiency, and more carbohydrate in 90-21-3 was translated into root. Compared with D937, 90-21-3 was able to rapidly accumulate proline, free amino acid and soluble sugar to keep the osmotic potential to alleviate osmotic stress and enhanced SOD, POD and CAT activity to promote the ability of degrading ROS after potassium starvation, alleviating the oxidative stress, which provided steady growth of root.

\section{Acknowledgements}

This program was jointly supported by National Natural Science Foundation of China (31771725).

\section{Conflicts of Interest}

The authors declare no conflicts of interest regarding the publication of this paper.

\section{References}

[1] Wang, Y., He, L., Li, H.D., Xu, J. and Wu, W.H. (2010) Potassium Channel Alpha-Subunit AtKC1 Negatively Regulates AKT1-Mediated $\mathrm{K}^{+}$Uptake in Arabidopsis Roots under Low-K ${ }^{+}$Stress. Cell Research, 20, 826-837. https://doi.org/10.1038/cr.2010.74

[2] Hu. W., Lv, X., Yang, J., Chen, B., Zhao, W., Meng, Y., Wang, Y., Zhou, Z. and Oosterhuis, D.M. (2016) Effects of Potassium Deficiency on Antioxidant Metabolism Related to Leaf Senescence in Cotton (Gossypium hirsutum L.). Field Crops Research, 191, 139-149. https://doi.org/10.1016/j.fcr.2016.02.025

[3] Zörb, C., Senbayram, M. and Peiter, E. (2014) Potassium in Agriculture: Status and Perspectives. Journal of Plant Physiology, 171, 656-669.

https://doi.org/10.1016/j.jplph.2013.08.008

[4] Cesco, S., Neumann, G., Tomasi, N., Pinton, R. and Weisskopf, L. (2010) Release of Plant-Borne Flavonoids into the Rhizosphere and Their Role in Plant Nutrition. Plant and Soil, 329, 1-25. https://doi.org/10.1007/s11104-009-0266-9

[5] Farhangi-Abriz, S. and Torabian, S. (2016) Antioxidant Enzyme and Osmotic Adjustment Changes in Bean Seedlings as Affected by Biochar under Salt Stress. Ecotoxicology and Environmental Safety, 137, 64-70. https://doi.org/10.1016/j.ecoenv.2016.11.029

[6] Hajlaoui. H., Ayeb, N.E., Garrec, J.P. and Denden M. (2010) Differential Effects of Salt Stress on Osmotic Adjustment and Solutes Allocation on the Basis of Root and Leaf Tissue Senescence of Two Silage Maize (Zea mays L.) Varieties. Industrial Crops and Products, 31, 122-130. https://doi.org/10.1016/j.indcrop.2009.09.007

[7] Kronzucker, H.J. and Britto, D.T. (2011) Sodium Transport in Plants: A Critical Review. New Phytologist, 189, 54-81. https://doi.org/10.1111/j.1469-8137.2010.03540.x

[8] Roosta, H.R., Estaji, A. and Niknam, F. (2018) Effect of Iron, Zinc and Manganese Shortage-Induced Change on Photosynthetic Pigments, Some Osmoregulators and Chlorophyll Fluorescence Parameters in Lettuce. Photosynthetica, 56, 606-615. https://doi.org/10.1007/s11099-017-0696-1 
[9] Hernandez, M., Fernandez-Garcia, N., Garcia-Garma, J., Rubio-Asensio, J.S., Rubio, F. and Olmos, E. (2012) Potassium Starvation Induces Oxidative Stress in Solanum lycopersicum L. Roots. Journal of Plant Physiology, 169, 1366-1374. https://doi.org/10.1016/j.jplph.2012.05.015

[10] Foyer, C.H., Descourvières, P. and Kunert, K.J. (2006) Protection against Oxygen Radicals: An Important Defence Mechanism Studied in Transgenic Plants. Plant, Cell and Environment, 17, 507-523. https://doi.org/10.1111/j.1365-3040.1994.tb00146.x

[11] Spychalla, J.P. and Desborough, S.L. (1990) Superoxide Dismutase, Catalase, and $\alpha$-Tocopherol Content of Stored Potato Tubers. Plant Physiology, 94, 1214-1218. https://doi.org/10.1104/pp.94.3.1214

[12] Shin, R. and Schachtman, D.P. (2004) Hydrogen Peroxide Mediates Plant Root Cell Response to Nutrient Deprivation. Proceedings of the National Academy of Sciences of the United States of America, 101, 8827-8832. https://doi.org/10.1073/pnas.0401707101

[13] Min, J.K., Ciani, S. and Schachtman, D.P. (2010) A Peroxidase Contributes to ROS Production during Arabidopsis Root Response to Potassium Deficiency. Molecular Plant, 3, 420-427. https://doi.org/10.1093/mp/ssp121

[14] Olmos, E. and Hellin, E. (1996) Mechanisms of Salt Tolerance in a Cell Line of Pisumsativum: Biochemical and Physiological Aspects. Plant Science, 120, 37-45. https://doi.org/10.1016/S0168-9452(96)04483-4

[15] Ennajeh, M., Vadel, A.M. and Khemira, H. (2009) Osmoregulation and Osmoprotection in the Leaf Cells of Two Olive Cultivars Subjected to Severe Water Deficit. Acta Physiologiae Plantarum, 31, 711-721. https://doi.org/10.1007/s11738-009-0283-6

[16] Chen, S., Zhao, H., Ding, G. and Xu, F. (2015) Genotypic Differences in Antioxidant Response to Phosphorus Deficiency in Brassica napus. Plant and Soil, 391, 19-32. https://doi.org/10.1007/s11104-015-2395-7

[17] Cao, M.J., Yu, H.Q., Yan, H.K. and Jiang, C.J. (2007) Difference in Tolerance to Potassium Deficiency between Two Maize Inbred Lines. Plant Production Science, 10, 42-46. https://doi.org/10.1626/pps.10.42

[18] Ashraf, M. and Zafar, Z.U. (1997) Effect of Potassium Deficiency on Growth and Some Biochemical Characteristics in Two Lines of Lentil (Lens culinaris Medic.). Acta Physiologiae Plantarum, 19, 9-15. https://doi.org/10.1007/s11738-997-0016-7

[19] Wan, Y.Y., Zhang, Y., Zhang, L., Zhou, Z.Q., Li, X., Shi, Q., Wang, X.J. and Bai, J.G. (2015) Caffeic Acid Protects Cucumber against Chilling Stress by Regulating Antioxidant Enzyme Activity and Proline and Soluble Sugar Contents. Acta Physiologiae Plantarum, 37, Article No. 1706. https://doi.org/10.1007/s11738-014-1706-6

[20] Bradford, M.M. (1976) A Rapid and Sensitive Method for the Quantitation of Microgram Quantities of Protein Utilizing the Principle of Protein-Dye Binding. Analytical Biochemistry, 72, 248-254. https://doi.org/10.1016/0003-2697(76)90527-3

[21] Tian, M., Gu, Q. and Zhu, M. (2003) The Involvement of Hydrogen Peroxide and Antioxidant Enzymes in the Process of Shoot Organogenesis of Strawberry Callus. Plant Science, 165, 701-707. https://doi.org/10.1016/S0168-9452(03)00224-3

[22] Tsai, Y.C., Hong, C.Y., Liu, L.F. and Kao, C.H. (2004) Relative Importance of $\mathrm{Na}^{+}$ and $\mathrm{Cl}^{-}$in NaCl-Induced Antioxidant Systems in Roots of Rice Seedlings. Physiologia Plantarum, 122, 86-94. https://doi.org/10.1111/j.1399-3054.2004.00387.x

[23] Mir, B.A., Mir, S.A., Khazir,J., Tonfack, L.B., Cowan, D.A., Vyas, D. and Koul, S. 
(2015) Cold Stress Affects Antioxidative Response and Accumulation of Medicinally Important Withanolides in Withania somnifera (L.) Dunal. Industrial Crops and Products, 74, 1008-1016. https://doi.org/10.1016/j.indcrop.2015.06.012

[24] Grace, S.C. and Logan, B.A. (1996) Acclimation of Foliar Antioxidant Systems to Growth Irradiance in Three Broad-Leaved Evergreen Species. Plant Physiology, 112, 1631-1640. https://doi.org/10.1104/pp.112.4.1631

[25] Neto, A.D.D.A., Prisco, J.T., Enéas-Filho, J., Abreu, C.E.B.D. and Gomes-Filho, E. (2006) Effect of Salt Stress on Antioxidative Enzymes and Lipid Peroxidation in Leaves and Roots of Salt-Tolerant and Salt-Sensitive Maize Genotypes. Environmental and Experimental Botany, 56, 87-94. https://doi.org/10.1016/j.envexpbot.2005.01.008

[26] Gerardeaux, E., Jordan-Meille, L., Constantin, J., Pellerin, S. and Dingkuhn, M. (2010) Changes in Plant Morphology and Dry Matter Partitioning Caused by Potassium Deficiency in Gossypium hirsutum (L.). Environmental and Experimental Botany, 67, 451-459. https://doi.org/10.1016/j.envexpbot.2009.09.008

[27] Jordan-Meille, L. and Pellerin, S. (2008) Shoot and Root Growth of Hydroponic Maize (Zea mays L.) as Influenced by K Deficiency. Plant and Soil, 304, 157-168. https://doi.org/10.1007/s11104-007-9534-8

[28] Tewari, R.K., Kumar, P., Tewari, N., Srivastava, S. and Sharma, P.N. (2004) Macronutrient Deficiencies and Differential Antioxidant Responses Influence on the Activity and Expression of Superoxide Dismutase in Maize. Plant Science, 166, 687-694. https://doi.org/10.1016/j.plantsci.2003.11.004

[29] Lebaudy, A., Véry, A.A. and Sentenac, H. (2007) $\mathrm{K}^{+}$Channel Activity in Plants: Genes, Regulations and Functions. FEBS Letters, 581, 2357-2366.

https://doi.org/10.1016/j.febslet.2007.03.058

[30] Fu, C., Li, M., Zhang, Y., Zhang, Y., Yan, Y. and Wang Y.A. (2015) Morphology, Photosynthesis, and Internal Structure Alterations in Field Apple Leaves under Hidden and Acute Zinc Deficiency. Scientia Horticulturae, 193, 47-54. https://doi.org/10.1016/j.scienta.2015.06.016

[31] Trovato, M., Mattioli, R. and Costantino, P. (2008) Multiple Roles of Proline in Plant Stress Tolerance and Development. Rendiconti Lincei, 19, 325-346. https://doi.org/10.1007/s12210-008-0022-8

[32] Li, R., Volenec, J.J. Joern, B.C. and Cunningham, S.M. (1997) Potassium and Nitrogen Effects on Carbohydrate and Protein Metabolism in Alfalfa Roots. Journal of Plant Nutrition, 20, 511-529. https://doi.org/10.1080/01904169709365271

[33] Armengaud, P., Sulpice, R., Miller, A.J., Stitt, M., Amtmann, A. and Gibon, Y. (2009) Multilevel Analysis of Primary Metabolism Provides New Insights into the Role of Potassium Nutrition for Glycolysis and Nitrogen Assimilation in Arabidopsis Roots. Plant Physiology, 150, 772-785. https://doi.org/10.1104/pp.108.133629

[34] Tang, Z.H., Zhang, A.J., Wei, M., Chen, X.G., Liu, Z.H., Li, H.M. and Ding, Y.F. (2015) Physiological Response to Potassium Deficiency in Three Sweet Potato (Ipomoea batatas [L.] Lam.) Genotypes Differing in Potassium Utilization Efficiency. Acta Physiologiae Plantarum, 37, Article No. 184.

https://doi.org/10.1007/s11738-015-1901-0

[35] Xu, W., Cui, K., Xu, A., Nie, L., Huang, J. and Peng, S. (2015) Drought Stress Condition Increases Root to Shoot Ratio via Alteration of Carbohydrate Partitioning and Enzymatic Activity in Rice Seedlings. Acta Physiologiae Plantarum, 37, Article No. 9. https://doi.org/10.1007/s11738-014-1760-0

[36] Wang, N., Hua, H., Egrinya, E.A., Li, Z., Duan, L. and Tian, X. (2012) Genotypic 
Variations in Photosynthetic and Physiological Adjustment to Potassium Deficiency in Cotton (Gossypium hirsutum). Journal of Photochemistry and Photobiology B: Biology, 110, 1-8. https://doi.org/10.1016/j.jphotobiol.2012.02.002

[37] Apel, K. and Hirt, H. (2004) Reactive Oxygen Species: Metabolism, Oxidative Stress, and Signal Transduction. Annual Review of Plant Biology, 55, 728-749. https://doi.org/10.1146/annurev.arplant.55.031903.141701

[38] Scandalios, J.G. (1993) Oxygen Stress and Superoxide Dismutases. Plant Physiology, 101, 7-12. https://doi.org/10.1104/pp.101.1.7 